\title{
A EDUCAÇÃO EM TEMPO INTEGRAL NO MUNICÍPIO DE ARARAS/SP E ANÁLISE DE SUA ESTRUTURA FRENTE ÀS REFORMAS EDUCACIONAIS A PARTIR DE 2016
}

\author{
Aline Andrade*, Evaldo Piolli.
}

\section{Resumo}

A pesquisa analisa a organização da oferta de educação em tempo integral no município de Araras (SP) e suas mutações frente às reformas educacionais recentes. A experiência municipal nesse campo começa com o Programa Mais Educação que vigorou até o ano de 2016, no último ano do governo Dilma. Com o golpe institucional de 2016, durante o Governo Temer, esse programa é reformulado e passa a ser denominado de Programa Novo Mais Educação. Na primeira versão, o programa tinha como foco a formação cultural que se dava pela oferta de atividades diversificadas no contra-turno escolar, já na segunda versão seu objetivo foi o reforço escolar com atenção para as disciplinas de Língua Portuguesa e Matemática. No entanto, as diversas medidas de cortes e reformas que foram adotadas a partir da EC 95/2016, levaram ao encerramento do programa no final de 2017 na cidade de Araras/SP. Para dar continuidade, o município passou a desenvolver um projeto próprio chamado de "Proposta de Atividades Extracurriculares da Educação Integral". Logo, trata-se de um trabalho que vem acompanhando essas mutações dos programas no município relacionadas ao contexto político nacional. Desse modo, colocamos duas questões problematizadoras: 1) quais as mutações da oferta de educação em tempo integral e a relação com as políticas nacionais; e, 2) como está a realização da oferta de educação em tempo integral em Araras/SP e quais os programas e as políticas que o município tem adotado?

\section{Palavras-chave: \\ Educação em Tempo Integral, Reformas Educacionais, Golpe Institucional de 2016.}

\section{Introdução}

O presente estudo nasceu de uma pesquisa realizada junto ao PROCAD (2016-2017) com o título de "Educação Integral e Educação em Tempo Integral no Programa Mais Educação: uma Experiência no Município de Araras", o trabalho parte de um breve estudo histórico da Educação Integral para, em seguida, compreender o modelo proposto no Programa Mais Educação (PME) a partir de 2010. Desse modo, essa pesquisa trata-se de uma continuidade da anterior, ao acompanhar as mutações dos programas em educação em tempo integral no município de Araras/SP, agora, relacionadas ao contexto político nacional a partir de 2016, objetivando identificar como está o cenário educacional brasileiro, principalmente aquele que diz respeito à educação integral.

\section{Resultados e Discussão}

Para melhor análise do cenário de educação integral brasileiro dentro do período, a pesquisa consistiu em estudos das reformas educacionais, tais como: a Reforma do Ensino Médio, Programa Mais Educação, Programa Novo Mais Educação, Programa Mais Alfabetização e a Base Nacional Comum Curricular, cujo objetivo foi compreender quais os direcionamentos da educação pública nacional e como ela vem se moldando, bem como, as implicações dessas reformas em relação à educação integral a partir da experiência do Município de Araras/SP. Isso posto, foi possível identificar um cenário cujas condições de oferta determinadas pelos limites do orçamento municipal e pela ausência de recursos federais estão se apresentando como mais precárias e restritas em muitas esferas.

\section{Conclusões}

As mutações identificadas no decorrer da pesquisa, evidenciaram a descontinuidade das políticas educacionais brasileiras a partir da experiência no município de Araras/SP, ou seja, a partir de 2016 o Brasil passou por três governos, sendo eles: Dilma Rousself, Michel Temer e atualmente Bolsonaro. Com o golpe institucional em 2016, o Brasil encaminhou uma série de reformas educacionais baseadas e articuladas com a BNCC, objetivando exclusivamente a redução de investimentos e como consequência reduzindo o indivíduo, tanto estudante quanto profissional, ao mínimo. Trata-se de uma era de retrocessos no campo educacional brasileiro e no que se refere à educação integral, hoje, cada vez mais vista e tratada como uma mercadoria.

\section{Agradecimentos}

Agradeço ao PIBIC pela oportunidade de que essa iniciação científica tornasse realidade e tão produtiva para o meu processo formativo enquanto educadora $\mathrm{e}$ pesquisadora. E meu sincero agradecimento ao meu orientador, Evaldo Piolli, que tanto se empenhou ao longo desse um ano a fim de problematizar diferentes questões acerca da temática, auxiliando-me na construção da pesquisa.

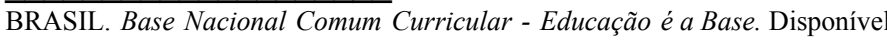
em: http://basenacionalcomum.mec.gov.br/abase/. Acesso em: 04 de Dezembro de 2018

KRAWCZYK, Nora; LOMBARDI, J.C (Org.). O Golpe de 2016 e a Educação Brasileira. Disponível

em: https://www.editoranavegando.com/livro-golpe-2016. Acesso em: 08 de Dezembro de 2018. 